\title{
Chemical Composition and Antibacterial Properties Survey of Salvia Mirzayanii Essential Oils in Different Ecological Conditions
}

\author{
Alieh Sadat Rafat Haghighi ${ }^{\mathrm{a}}$, Amir Borjian ${ }^{\mathrm{b}}$ \\ ${ }^{a}$ Department of Medicinal Plants, Islamic Azad University, Jahrom Branch. Jahrom. Iran. \\ ${ }^{\mathrm{b}}$ Department of Plant Biology, Islamic Azad University, Jahrom Branch. Jahrom. Iran.
}

\begin{abstract}
Chemical composition and antimicrobial effects of essential oils derived from Salvia mirzayanii were determined using GC and GC/MS. In this research four habitats in Larestan region were determined (A$D)$.The results showed that ecological factors had significant effect on oil yields of S. mirzayanii. The components were various in different regions. Linalyl acetate (18.64\%), 5-neo-cedranol (17.43\%), a-Terpinyl acetate (10.81\%), 7-epi-a-selinene (9.18\%), Bicyclogermacrene (5.33), Linalool (4.77\%), 1,8-Cineol (4.53\%) were the main components. The antimicrobial activity of essential oil of S. mirzayanii was studied against three bacteria (Shigella dysenteriae, Staphylococcus aureus and Escherichia coli). Antimicrobial activities according to the disk diffusion method and MIC values were performed and showed that essential oils of S. mirzayanii revealed antimicrobial activity against bacteria in all regions. In all microorganisms MIC value was 0.625 $\mu \mathrm{l} / \mathrm{ml}$ and inhibition zones ranged from 8 to $17.67 \mathrm{~mm}$. The maximum and minimum antimicrobial activity was observed on Staphylococcus aureus and Escherichia coli, respectively.
\end{abstract}

Keywords: Antimicrobial activity, essential oil, Salvia mirzayanii.

\section{INTRODUCTION}

Salvia is an important genus from the Lamiaceae with approximately 900 species and represented in Flora iranica by 58 species(1). Salvia mirzayanii Rech. f. \& Esfand. ("Moor-e-Talkh" in local language) is one of the native species. This plant distributed in central and southern parts of Iran. Salvia mirzayanii is growing as a biennial or perennial flowering plants (2). Local people usually used Salvia mirzayanii for colds, hemostatic and infections (3). This species used as an astringent and tonic in Iranian folk medicine (4). In addition, several studies have shown the various biological activities of this plant including antiplasmodial, antidiabetic, antioxidant, antifungal, antibacterial activity, antiHIV, antimalarial, cytotoxicity, antitumor and cardiotonic properties (5).

The pharmacological effects of Salvia essential oils are based on the presence of more than 100 active elements which can be classified into Monoterpene hydrocarbons, Oxygenated monoterpenes, Sesquiterpene hydrocarbons, Diterpenes, Not iso-prenoid compounds and Oxygenated sesquiterpenes. The major components contain 1, 8-cineole, camphor, borneol, $\beta$-pinene, $\alpha$ - pinene, camphene and $\alpha$ thujene (6). By Javidnia et al. (7) spathulenol, $\delta$-cadinene, linalool, $\alpha$-terpinyl acetate, $\alpha$-cadinol, $\beta$ eudesmol, cubenol and linalyl acetate were reported to be the main components of $S$. mirzayanii essential oil. In another study, Yamini et al. (8) reported that, linalyl acetate, 1,8-cineole, linalool and 8- acetoxy linalool were the major components in S. mirzayanii essential oil.

The essential oils of extracted from $S$. mirzayanii have recently been investigated, showing strong antimicrobial activity. Sonboli et al. (9) demonstrated that $S$. mirzayanii essential oils exhibited antimicrobial activity. Results of other study showed $S$. mirzayanii was rich in 1,8-cineol and exhibited strong antimicrobial activity against tested microbes, in this study demonstrated that 1,8cineol has significant antimicrobial activities (10). Haghighat et al. (11) reported that the major components in S. mirzayanii oil were 5-neocedranol, $\alpha$-terpinyl acetate,1,8-cineol, bicyclogermacrene, $\delta$-cadinene, Globulol, $\alpha$-cadinol, tau-cadinol, 7 -epi- $\alpha$-selinene, Linalyl acetate, Linalool, $\beta$-Elemene, $\gamma$-cadinene and $\alpha$-guaiene and the oil showed good antimicrobial activity against Fusarium solani, Staphylococcus aureus and Candida albicans. 
In the current study, we investigated the chemical composition of the essential oils from the aerial parts of Salvia mirzayanii. Furthermore, antimicrobial activity of the essential oils obtained from this plant was evaluated against Sh. dysenteriae, E. coli $O 157$ and S. aureus.

\section{MATERIAL AND MeTHODS}

\subsection{Plant Material}

The aerial parts of $S$. mirzayanii were collected in june 2012 at flowering stage from four habitats in Larestan region: (A) center of Lar, Sahraye nimeh, (B) north of Lar, Dehkuieh, (C) south of Lar, Kuh perdi, (D) northeast of Lar, Dresosaiban. Features of this region and soil properties listed in table 1 and 2. Plant materials were identified in the Herbarium of Medicinal and Aromatic Plants, Islamic Azad University, Jahrom, Iran. Harvested plants were dried at temperature below $30^{\circ} \mathrm{c}$ for 15 days.

Table1. Collection site information (Meteorological Center, Larestan, Iran)

\begin{tabular}{|l|c|c|c|c|c|c|c|c|}
\hline Site & Latitude & Longitude & $\begin{array}{c}\text { Elevation } \\
\mathbf{( M )}\end{array}$ & $\begin{array}{c}\text { Average } \\
\text { of } \\
\text { Relative } \\
\text { Humidity } \\
\mathbf{( \% )}\end{array}$ & $\begin{array}{c}\text { Total } \\
\text { Annual } \\
\text { Evaporation } \\
\mathbf{( M m )}\end{array}$ & $\begin{array}{c}\text { Mean } \\
\text { Annual } \\
\text { Rainfall } \\
\mathbf{( M m )}\end{array}$ & $\begin{array}{c}\text { Max } \\
\text { Temperature } \\
(\mathbf{0} \mathbf{c})\end{array}$ & $\begin{array}{c}\text { Min } \\
\text { Temperature } \\
\mathbf{(}^{\mathbf{(} \mathbf{c})}\end{array}$ \\
\hline $\mathrm{A}$ & $54^{\circ} 2301.94$ & $27^{\circ} 3334.30$ & 1115 & 42 & 3321.5 & 203 & 47.8 & -4.8 \\
\hline $\mathrm{B}$ & $54^{\circ} 2539.18$ & $27^{\circ} 5609.17^{\prime \prime}$ & 1315 & 47 & 3248.5 & 211.2 & 45 & -7 \\
\hline $\mathrm{C}$ & $54^{\circ} 1644.27^{\prime \prime}$ & $27^{\circ} 2809.32$ & 2100 & 50 & 3102 & 223 & 35 & -12 \\
\hline $\mathrm{D}$ & $55^{\circ} 3309.45^{\prime \prime}$ & $27^{\circ} 5329.06$ & 987 & 37 & 4015 & 185 & 50 & -2 \\
\hline
\end{tabular}

\subsection{Essential Oil Extraction}

Essential oil was extracted from dried and powdered aerial parts (100 g) of S.mirzayanii by hydrodistillation using glass Clevenger type apparatus during approximately 3 hours. The distilled essential oil was dried using anhydrous sodium sulfate. The essential oil was weighted and stored in refrigerator at $4^{\circ} \mathrm{C}$ until analysis (12).

\subsection{Essential Oil Analysis}

Gas chromatographic analysis was performed using an Agilent Technologies gas chromatographer (model 6890A, USA) equipped with a flame ionization detector (FID) and a DB-5 fused silica capillary column $(30 \mathrm{~m} \times 0.32 \mathrm{~mm}$, film thickness $0.25 \mu \mathrm{m})$. The oven temperature was $140^{\circ} \mathrm{C}$. Helium was used as the carrier gas. The samples were injected using split sampling technique by a ratio of 1.50.GC-MS analysis was carried out using an Agilent Technologies GC-MS (model 6890 C) equipped with fused silica capillary DB-5 column $(30 \mathrm{~m} \times 0.25 \mathrm{~mm}, 0.25 \mu \mathrm{m}$ film thickness $)$ with Helium as the carrier gas and a split ratio of 1.50(13).

Table2. Physico- chemical properties of the experimental soil (Soil Science Laboratory, Shiraz, Iran)

\begin{tabular}{|c|c|c|c|c|c|c|c|c|c|c|c|c|c|c|}
\hline \multirow[t]{3}{*}{ Region } & \multicolumn{14}{|c|}{ Soil properties } \\
\hline & \multicolumn{2}{|c|}{ Acidity $(\mathrm{pH})$} & \multicolumn{2}{|c|}{$\begin{array}{c}\text { Electrical } \\
\text { conductivity } \\
(\mathrm{EC})\end{array}$} & \multicolumn{2}{|c|}{ Humidity (\%) } & \multicolumn{2}{|c|}{ Phosphorous } & \multicolumn{2}{|c|}{$\begin{array}{l}\text { Potassium } \\
\text { (K) }\end{array}$} & \multicolumn{2}{|c|}{$\begin{array}{c}\text { Carbon } \\
\text { (OC) }\end{array}$} & \multicolumn{2}{|c|}{ Nitrogen $(\mathrm{N})$} \\
\hline & mean & $\begin{array}{c}\text { F- } \\
\text { value }\end{array}$ & mean & $\begin{array}{c}\text { F- } \\
\text { value }\end{array}$ & mean & $\begin{array}{c}\text { F- } \\
\text { value }\end{array}$ & mean & $\begin{array}{c}\text { F- } \\
\text { value }\end{array}$ & mean & $\begin{array}{c}\text { F- } \\
\text { value }\end{array}$ & mean & $\begin{array}{c}\text { F- } \\
\text { value }\end{array}$ & mean & mean \\
\hline $\mathrm{A}$ & 7.61 & \multirow{4}{*}{$0.02^{\mathrm{ns}}$} & 1.42 & \multirow{4}{*}{$52.37^{* *}$} & 33.3 & \multirow{4}{*}{$75.24^{* *}$} & 7.72 & \multirow{4}{*}{$579^{* *}$} & 154 & \multirow{4}{*}{$249^{* *}$} & 1.32 & \multirow{4}{*}{$43^{* *}$} & 0.12 & \multirow{4}{*}{$9.06^{* *}$} \\
\hline $\mathrm{B}$ & 7.63 & & 1.08 & & 43 & & 0.72 & & 160 & & 0.93 & & 0.09 & \\
\hline $\mathrm{C}$ & 7.57 & & 1.55 & & 38.33 & & 8.67 & & 243 & & 0.98 & & 0.1 & \\
\hline $\mathrm{D}$ & 7.52 & & 1.55 & & 57.33 & & 26.33 & & 232 & & 2.51 & & 0.25 & \\
\hline
\end{tabular}

\begin{tabular}{|c|c|c|c|c|c|c|c|c|}
\hline \multirow[t]{3}{*}{ Region } & \multicolumn{8}{|c|}{ Soil properties } \\
\hline & \multicolumn{2}{|c|}{ Sand } & \multicolumn{2}{|c|}{ Silt } & \multicolumn{2}{|c|}{ Clay } & \multicolumn{2}{|c|}{ TNV } \\
\hline & F-value & F-value & mean & F-value & mean & F-value & mean & F-value \\
\hline A & 75 & \multirow{4}{*}{$265^{* *}$} & 25 & \multirow{4}{*}{$169^{* *}$} & 0.01 & \multirow{4}{*}{$104^{* *}$} & 16.6 & \multirow{4}{*}{$310^{* *}$} \\
\hline B & 51 & & 41 & & 7.97 & & 21.42 & \\
\hline $\mathrm{C}$ & 39 & & 53 & & 7.87 & & 39.43 & \\
\hline $\mathrm{D}$ & 47 & & 47 & & 6.07 & & 52.43 & \\
\hline
\end{tabular}

$*, * *=$ Significant at $5 \%$ and $1 \%$, respectively, $n s=$ Non-significant 


\subsection{Microorganisms}

The antimicrobial activities of essential oils were tested against standard strain of Gram-positive bacteria Staphylococcus aureus (ATCC 6538), Shigella dysenteriae (RI366), Escherichia coli (O157:H7 EPEC (M). This strain was obtained from Persian Type Culture Collection (PTCC) in Iranian Research Organization for Science and Technology.

\subsection{Antimicrobial Activity Survey}

Antimicrobial activity of essential oil of S. mirzayanii was evaluated by using disc diffusion method, according to the National Committee for Clinical Laboratory Standards (14). The inoculants of the microbial strains were prepared from freshly cultured bacteria that were adjusted to0.5 McFarland standard turbidity (15).Tested bacteria strains were suspended in the agar media and the plates (treated wells and untreated controls) were incubated in a humid atmosphere at $30^{\circ} \mathrm{C}$ for 24 hours(16(.The essential oil was dissolved in dimethyl sulfoxide (DMSO), and diluted in a twofold manner to make the concentrations of $0.625,1.25,2.5,5,10$ and $20 \mu \mathrm{l} / \mathrm{disc}$. These plates were incubated for 24 hours at $35-37^{\circ} \mathrm{C}$. After the incubation period, the diameter of inhibition zone (IZ) was measured in millimeters. The minimum inhibitory concentration (MIC) of the essential oil was determined through a serial dilution method. MICs is visually determined and defined as the lowest concentration of the essential oil producing no visible growth. Each experiment was performed in triplicate.

Analysis of variance was performed by ANOVA by the software SAS. Significant differences between means were determined by Duncan's new multiple-range test. Correlations among data were calculated using Pearson's correlation coefficient.

\section{RESUlTS AND Discussion}

\subsection{Chemical Composition of the Essential Oil}

The essential oil of the aerial parts of $S$. santolinifolia was obtained as a light yellow liquid with a yield of $1.6 \%(\mathrm{w} / \mathrm{w})$, based on dry weight. The results showed that ecological factors had significant effect on oil yields of $S$. mirzayanii (Table 3). Identification of chemical constituents of the essential oils showed that the components were various in different regions (Table 4).GC/FID and GC/MS analysis identified forty-six and forty-three components in the essential oil of $S$. mirzayanii that represented 95.26\%and 94.94\% of the oils in B region (max) and A region (min), respectively. Also, forty-four and forty-five components were identified in the essential oil of S. mirzayaniiin C region and $\mathrm{D}$ region, respectively.

Table3. Variance analysis of S. mirzayanii essential weight and yield

\begin{tabular}{|c|c|c|c|}
\hline S.O.V & \multirow{2}{*}{ Df } & \multicolumn{2}{|c|}{ Mean Squares } \\
\cline { 3 - 4 } & & Essential Weight & Essential Yield \\
\hline Treatment & 3 & $0.367^{* *}$ & $0.06^{* *}$ \\
\hline Experimental error & 8 & $0.002^{* *}$ & $0.003^{* *}$ \\
\hline Coefficient of variation (\%) & - & 5.45 & 7.79 \\
\hline
\end{tabular}

**** and $n s$ is significant at probability level of 1 and non-significant at $5 \%$, respectively.

Table4. Essential weight and yield of S. mirzayanii in different region

\begin{tabular}{|c|c|c|}
\hline Region & Essential weight & Essential yield \\
\hline A & $0.51 \mathrm{c}$ & $0.78 \mathrm{~b}$ \\
\hline B & $0.68 \mathrm{c}$ & $1.23 \mathrm{c}$ \\
\hline C & $1.3 \mathrm{a}$ & $1.33 \mathrm{a}$ \\
\hline D & $0.71 \mathrm{~b}$ & $0.69 \mathrm{~b}$ \\
\hline
\end{tabular}

In a column, means with the same letters are not significantly different

The major components were 5- neo-cedranol (17.43\%), Linalyl acetate (15.89\%), 7-epi- $\alpha$-selinene (9.18\%), Spatolenol (7.46\%), $\alpha$-terpinyl acetate (4.66\%), bicyclogermacrene (4.59\%), Linalool (4.37\%), Germacrene - d- 4- ol (4.30\%) (A region), Linalyl acetate (15.89\%), 5- neo-cedranol (11.42\%), $\alpha$-terpinyl acetate (10.81\%), Spatolenol (5.81\%), Linalool (4.77\%), bicyclogermacrene (4.59\%), 1,8-cineol (4.53\%), 7-epi- $\alpha$-selinene (4.17) (B region), Linalyl acetate (13.10\%), 5- neocedranol (12.83\%), Spatolenol (8.18\%), bicyclogermacrene (5.33\%), 7-epi- $\alpha$-selinene (4.88\%), $\alpha$ Terpineol (4.71\%), $\alpha$-cadinol (4.36\%) (C region) and Linalyl acetate (18.64\%), 5- neo-cedranol 
Alieh Sadat Rafat Haghighi \& Amir Borjian

(9.75\%), Spatolenol (8.68\%), 7-epi- $\alpha$-selinene (7.28\%), Linalool (6.17\%), $\alpha$-terpinyl acetate (6.16\%) (Dregion). Other components were present in amounts less than 4\% (Table 5-8). The main components observed in the essential oil of $S$. mirzayanii in each region were different. The peaks in the chromatogram showed major components in essential oil in each region (Figure 1-4).

Table5. Chemical composition of the essential oil in A region

\begin{tabular}{|c|c|c|c|}
\hline No & Compounds & RI & Oil percentage \\
\hline 1 & a-Thujene & 926.4 & 0.029 \\
\hline 2 & a-Pinene & 933.7 & 0.090 \\
\hline 3 & Sabinene & 973.7 & 0.039 \\
\hline 4 & b-Pinene & 978.2 & 0.137 \\
\hline 5 & Myrcene & 990.5 & 0.462 \\
\hline 6 & n-octanal & 996.4 & 0.740 \\
\hline 7 & Limonene & 1029 & 0.202 \\
\hline 8 & 1,8-Cineol & 1036 & 2.312 \\
\hline 9 & trans-b-Ocimene & 1046 & 0.297 \\
\hline 10 & trans-linalool oxide & 1078 & 0.438 \\
\hline 11 & Terpinolene & 1089 & 0.141 \\
\hline 12 & Linalool & 1105 & 4.373 \\
\hline 13 & trans-Pinocarveol & 1130 & 0.105 \\
\hline 14 & trans-verbenol & 1158 & 0.492 \\
\hline 15 & P-mentha-1,5-dien-8-ol & 1172 & 0.328 \\
\hline 16 & Terpinene-4-ol & 1182 & 0.206 \\
\hline 17 & a-Terpineol & 1197 & 1.731 \\
\hline 18 & trans-Carveol & 1212 & 0.341 \\
\hline 19 & Nerol & 1233 & 0.355 \\
\hline 20 & Linalyl acetate & 1261 & 9.114 \\
\hline 21 & n-Decanol & 1275 & 0.483 \\
\hline 22 & d-Elemene & 1338 & 0.693 \\
\hline 23 & a-Terpinyl acetate & 1355 & 4.661 \\
\hline 24 & Neryl acetate & 1368 & 0.461 \\
\hline 25 & Geranyl acetate & 1388 & 1.003 \\
\hline 26 & b-Elemene & 1394 & 1.446 \\
\hline 27 & a-Gurjunene & 1412 & 0.846 \\
\hline 28 & (E)-Caryophyllene & 1422 & 0.607 \\
\hline 29 & a-Guaiene & 1441 & 0.938 \\
\hline 30 & g-Muurolene & 1478 & 0.877 \\
\hline 31 & b-Selinene & 1489 & 0.884 \\
\hline 32 & Bicyclogermacrene & 1501 & 6.848 \\
\hline 33 & a-Muurolene & 1517 & 1.436 \\
\hline 34 & 7-epi-a-selinene & 1528 & 9.189 \\
\hline 35 & d-Cadinene & 1533 & 2.697 \\
\hline 36 & Germacrene D-4-ol & 1583 & 4.305 \\
\hline 37 & Spathulenol & 1588 & 7.460 \\
\hline 38 & Globulol & 1592 & 0.783 \\
\hline 39 & epi-a-Cadinol & 1647 & 2.119 \\
\hline 40 & epi-a-Muurolol & 1649 & 1.440 \\
\hline 41 & b-Eudesmol & 1659 & 2.581 \\
\hline 42 & a-Cadinol & 1664 & 4.137 \\
\hline \multirow[t]{3}{*}{43} & 5-neo-cedranol & 1705 & 17.437 \\
\hline & Oil Yield (\%w/w) & & 0.78 \\
\hline & Total & & 95.263 \\
\hline
\end{tabular}


Chemical Composition and Antibacterial Properties Survey of Salvia Mirzayanii Essential Oils in Different Ecological Conditions

Table6. Chemical composition of the essential oil in $\boldsymbol{B}$ region

\begin{tabular}{|c|c|c|c|}
\hline No & Compounds & RI & Oil percentage \\
\hline 2 & a-Pinene & 933.9 & 0.141 \\
\hline 3 & Sabinene & 973.9 & 0.141 \\
\hline 4 & b-Pinene & 978.4 & 0.239 \\
\hline 5 & Myrcene & 990.5 & 0.605 \\
\hline 6 & n-octanal & 996.8 & 1.211 \\
\hline 7 & a-terpinene & 1016 & 0.166 \\
\hline 8 & p-Cymene & 1025 & 0.142 \\
\hline 9 & Limonene & 1029 & 0.317 \\
\hline 10 & 1,8-Cineol & 1037 & 4.534 \\
\hline 11 & trans-b-Ocimene & 1047 & 0.320 \\
\hline 12 & trans-linalool oxide & 1079 & 0.689 \\
\hline 13 & Terpinolene & 1089 & 0.180 \\
\hline 14 & Linalool & 1105 & 4.770 \\
\hline 15 & trans-Pinocarveol & 1144 & 0.201 \\
\hline 16 & trans-verbenol & 1159 & 0.527 \\
\hline 17 & P-mentha-1,5-dien-8-ol & 1172 & 0.648 \\
\hline 18 & Terpinene-4-ol & 1182 & 0.285 \\
\hline 19 & a-Terpineol & 1197 & 2.274 \\
\hline 20 & trans-Carveol & 1213 & 0.422 \\
\hline 21 & Nerol & 1234 & 0.433 \\
\hline 22 & Linalyl acetate & 1263 & 15.891 \\
\hline 23 & n-Decanol & 1276 & 0.730 \\
\hline 24 & d-Elemene & 1338 & 0.334 \\
\hline 25 & a-Terpinyl acetate & 1358 & 10.817 \\
\hline 26 & Neryl acetate & 1368 & 0.514 \\
\hline 27 & Geranyl acetate & 1388 & 1.003 \\
\hline 28 & b-Elemene & 1394 & 0.937 \\
\hline 29 & a-Gurjunene & 1412 & 0.513 \\
\hline 30 & (E)-Caryophyllene & 1422 & 0.506 \\
\hline 31 & a-Guaiene & 1444 & 1.355 \\
\hline 32 & allo-Aromadendrene & 1461 & 0.331 \\
\hline 33 & g-Muurolene & 1478 & 0.702 \\
\hline 34 & b-Selinene & 1489 & 0.556 \\
\hline 35 & Bicyclogermacrene & 1501 & 4.595 \\
\hline 36 & a-Muurolene & 1517 & 0.905 \\
\hline 37 & g-Cadinene & 1525 & 2.110 \\
\hline 38 & 7-epi-a-selinene & 1528 & 4.178 \\
\hline 39 & d-Cadinene & 1532 & 1.151 \\
\hline 40 & Germacrene D-4-ol & 1583 & 2.730 \\
\hline 41 & Spathulenol & 1588 & 5.810 \\
\hline 42 & Globulol & 1592 & 0.414 \\
\hline 43 & epi-a-Muurolol & 1649 & 2.866 \\
\hline 44 & b-Eudesmol & 1659 & 2.384 \\
\hline 45 & a-Cadinol & 1664 & 3.892 \\
\hline \multirow[t]{3}{*}{46} & 5-neo-cedranol & 1704 & 11.421 \\
\hline & Oil Yield $(\% \mathrm{w} / \mathrm{w})$ & & 0.052 \\
\hline & Total & & 94.942 \\
\hline
\end{tabular}


Alieh Sadat Rafat Haghighi \& Amir Borjian

Table7. Chemical composition of the essential oil in $\mathbf{C}$ region

\begin{tabular}{|c|c|c|c|}
\hline No & Compounds & RI & Oil percentage \\
\hline 1 & a-Thujene & 926.4 & 0.036 \\
\hline 2 & a-Pinene & 933.8 & 0.180 \\
\hline 3 & Sabinene & 973.8 & 0.069 \\
\hline 4 & b-Pinene & 978.4 & 0.315 \\
\hline 5 & Myrcene & 990.2 & 0.477 \\
\hline 6 & n-octanal & 996.4 & 0.939 \\
\hline 7 & Limonene & 1029 & 0.340 \\
\hline 8 & 1,8-Cineol & 1036 & 1.681 \\
\hline 9 & trans-b-Ocimene & 1046 & 0.302 \\
\hline 10 & trans-linalool oxide & 1078 & 0.529 \\
\hline 11 & Linalool & 1105 & 3.955 \\
\hline 12 & trans-Pinocarveol & 1130 & 0.187 \\
\hline 13 & trans-verbenol & 1158 & 0.752 \\
\hline 14 & P-mentha-1,5-dien-8-ol & 1172 & 0.389 \\
\hline 15 & a-Terpineol & 1197 & 1.737 \\
\hline 16 & trans-Carveol & 1213 & 0.489 \\
\hline 17 & Nerol & 1234 & 0.384 \\
\hline 18 & Linalyl acetate & 1262 & 13.104 \\
\hline 19 & n-Decanol & 1275 & 0.573 \\
\hline 20 & d-Elemene & 1338 & 0.537 \\
\hline 21 & a-Terpinyl acetate & 1355 & 4.714 \\
\hline 22 & Neryl acetate & 1368 & 0.472 \\
\hline 23 & a-Copaene & 1381 & 0.401 \\
\hline 24 & Geranyl acetate & 1387 & 1.013 \\
\hline 25 & b-Elemene & 1394 & 1.208 \\
\hline 26 & a-Gurjunene & 1412 & 0.666 \\
\hline 27 & (E)-Caryophyllene & 1421 & 0.623 \\
\hline 28 & a-Guaiene & 1444 & 2.201 \\
\hline 29 & allo-Aromadendrene & 1461 & 0.674 \\
\hline 30 & g-Muurolene & 1478 & 0.918 \\
\hline 31 & b-Selinene & 1489 & 0.748 \\
\hline 32 & Bicyclogermacrene & 1500 & 5.334 \\
\hline 33 & a-Muurolene & 1517 & 1.238 \\
\hline 34 & g-Cadinene & 1525 & 3.415 \\
\hline 35 & 7-epi-a-selinene & 1528 & 4.881 \\
\hline 36 & d-Cadinene & 1532 & 2.039 \\
\hline 37 & Germacrene D-4-ol & 1583 & 3.258 \\
\hline 38 & Spathulenol & 1588 & 8.180 \\
\hline 39 & Globulol & 1592 & 0.674 \\
\hline 40 & epi-a-Cadinol & 1647 & 1.826 \\
\hline 41 & epi-a-Muurolol & 1649 & 1.640 \\
\hline 42 & b-Eudesmol & 1659 & 3.579 \\
\hline 43 & a-Cadinol & 1663 & 4.362 \\
\hline \multirow[t]{3}{*}{44} & 5-neo-cedranol & 1703 & 12.835 \\
\hline & Oil Yield $(\% \mathrm{w} / \mathrm{w})$ & & 0.690 \\
\hline & Total & & 93.874 \\
\hline
\end{tabular}


Chemical Composition and Antibacterial Properties Survey of Salvia Mirzayanii Essential Oils in Different Ecological Conditions

Table8. Chemical composition of the essential oil in $\mathbf{D}$ region

\begin{tabular}{|c|c|c|c|}
\hline No & Compounds & RI & Oil percentage \\
\hline 1 & a-Thujene & 926.3 & 0.070 \\
\hline 2 & a-Pinene & 933.8 & 0.189 \\
\hline 3 & Sabinene & 973.7 & 0.105 \\
\hline 4 & b-Pinene & 978.2 & 0.314 \\
\hline 5 & Myrcene & 990.3 & 0.817 \\
\hline 6 & n-octanal & 996.4 & 0.785 \\
\hline 7 & $p$-Cymene & 1025 & 0.143 \\
\hline 8 & Limonene & 1029 & 0.349 \\
\hline 9 & 1,8-Cineol & 1036 & 2.637 \\
\hline 10 & trans-b-Ocimene & 1046 & 0.458 \\
\hline 11 & g-Terpinene & 1058 & 0.069 \\
\hline 12 & trans-linalool oxide & 1078 & 0.748 \\
\hline 13 & Terpinolene & 1089 & 0.187 \\
\hline 14 & Linalool & 1106 & 6.178 \\
\hline 15 & trans-Pinocarveol & 1130 & 0.172 \\
\hline 16 & trans-verbenol & 1158 & 0.671 \\
\hline 17 & P-mentha-1,5-dien-8-ol & 1172 & 0.349 \\
\hline 18 & Terpinene-4-ol & 1182 & 0.163 \\
\hline 19 & a-Terpineol & 1197 & 2.227 \\
\hline 20 & trans-Carveol & 1213 & 0.424 \\
\hline 21 & Nerol & 1234 & 0.466 \\
\hline 22 & Linalyl acetate & 1263 & 18.643 \\
\hline 23 & n-Decanol & 1276 & 0.672 \\
\hline 24 & d-Elemene & 1338 & 0.494 \\
\hline 25 & a-Terpinyl acetate & 1356 & 6.166 \\
\hline 26 & Neryl acetate & 1368 & 0.699 \\
\hline 27 & a-Copaene & 1382 & 0.560 \\
\hline 28 & Geranyl acetate & 1388 & 1.389 \\
\hline 29 & b-Elemene & 1394 & 0.987 \\
\hline 30 & a-Gurjunene & 1412 & 0.563 \\
\hline 31 & (E)-Caryophyllene & 1422 & 0.577 \\
\hline 32 & a-Guaiene & 1444 & 2.385 \\
\hline 33 & allo-Aromadendrene & 1461 & 0.696 \\
\hline 34 & g-Muurolene & 1478 & 0.767 \\
\hline 35 & b-Selinene & 1489 & 0.652 \\
\hline 36 & Bicyclogermacrene & 1501 & 4.888 \\
\hline 37 & a-Muurolene & 1517 & 1.210 \\
\hline 38 & 7-epi-a-selinene & 1528 & 7.282 \\
\hline 39 & d-Cadinene & 1532 & 1.559 \\
\hline 40 & Spathulenol & 1588 & 8.685 \\
\hline 41 & Globulol & 1592 & 0.493 \\
\hline 42 & epi-a-Cadinol & 1647 & 2.950 \\
\hline 43 & b-Eudesmol & 1659 & 2.233 \\
\hline 44 & a-Cadinol & 1663 & 3.127 \\
\hline \multirow[t]{3}{*}{45} & 5-neo-cedranol & 1703 & 9.759 \\
\hline & Oil Yield $(\% \mathrm{w} / \mathrm{w})$ & & 1.310 \\
\hline & Total & & 94.957 \\
\hline
\end{tabular}




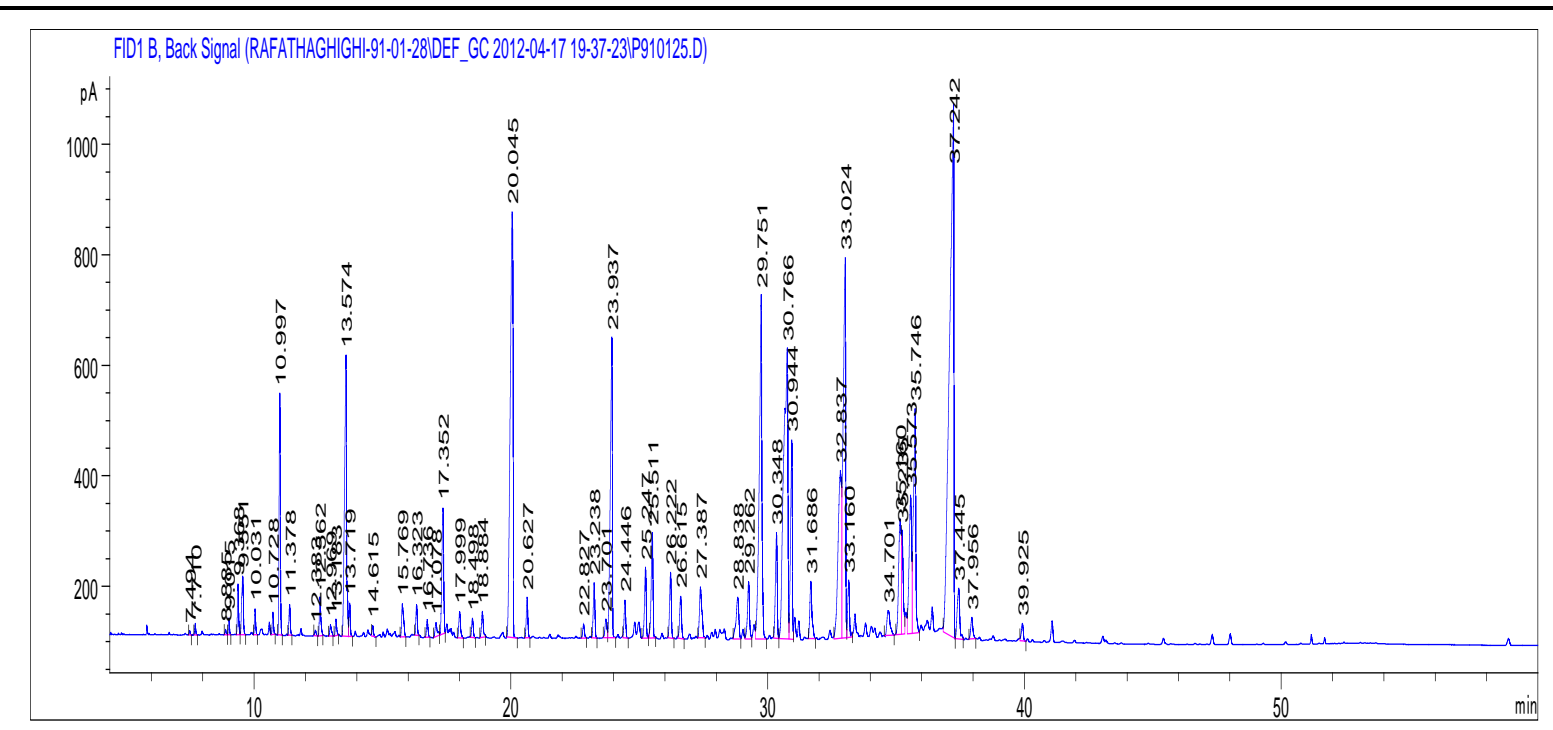

Figure1. GC-MS chromatogram of S. mirzayanii essential oil in A region

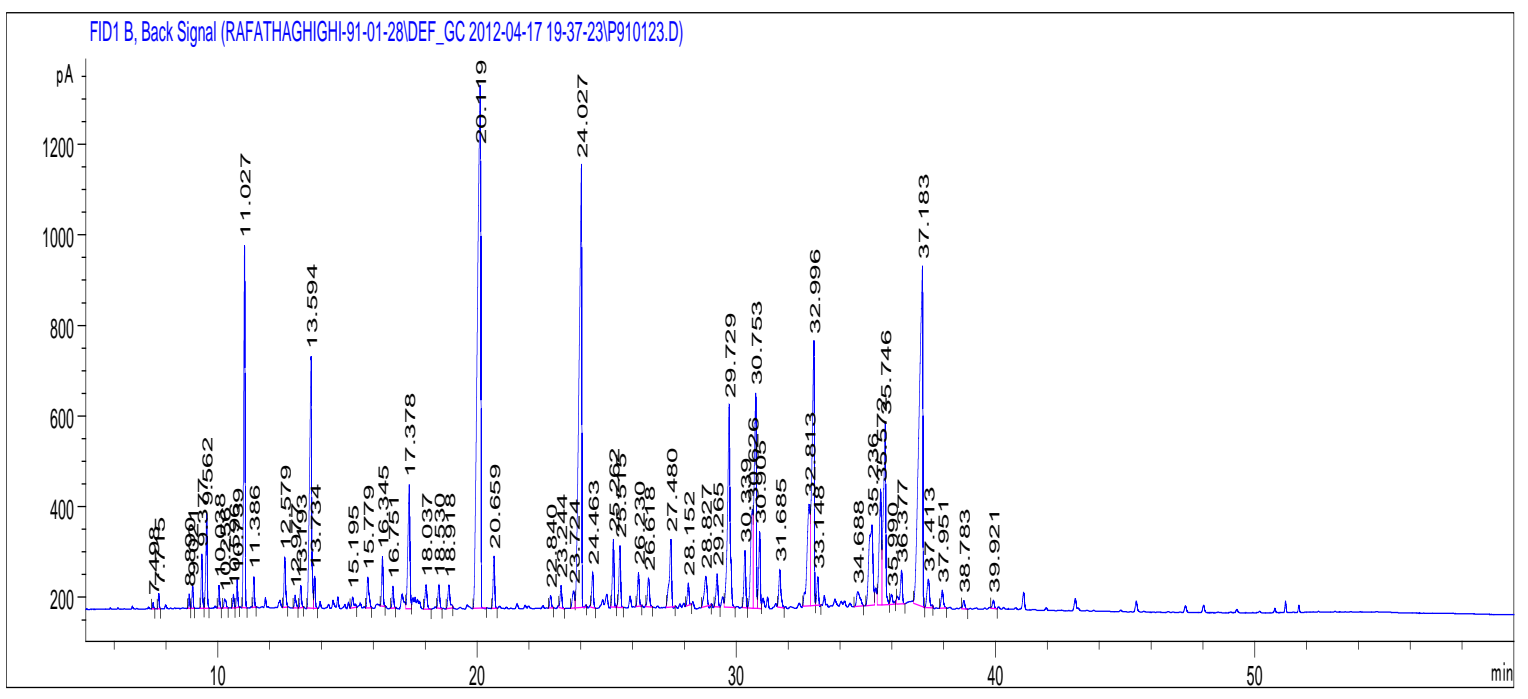

Figure2. GC-MS chromatogram of S. mirzayanii essential oil in B region

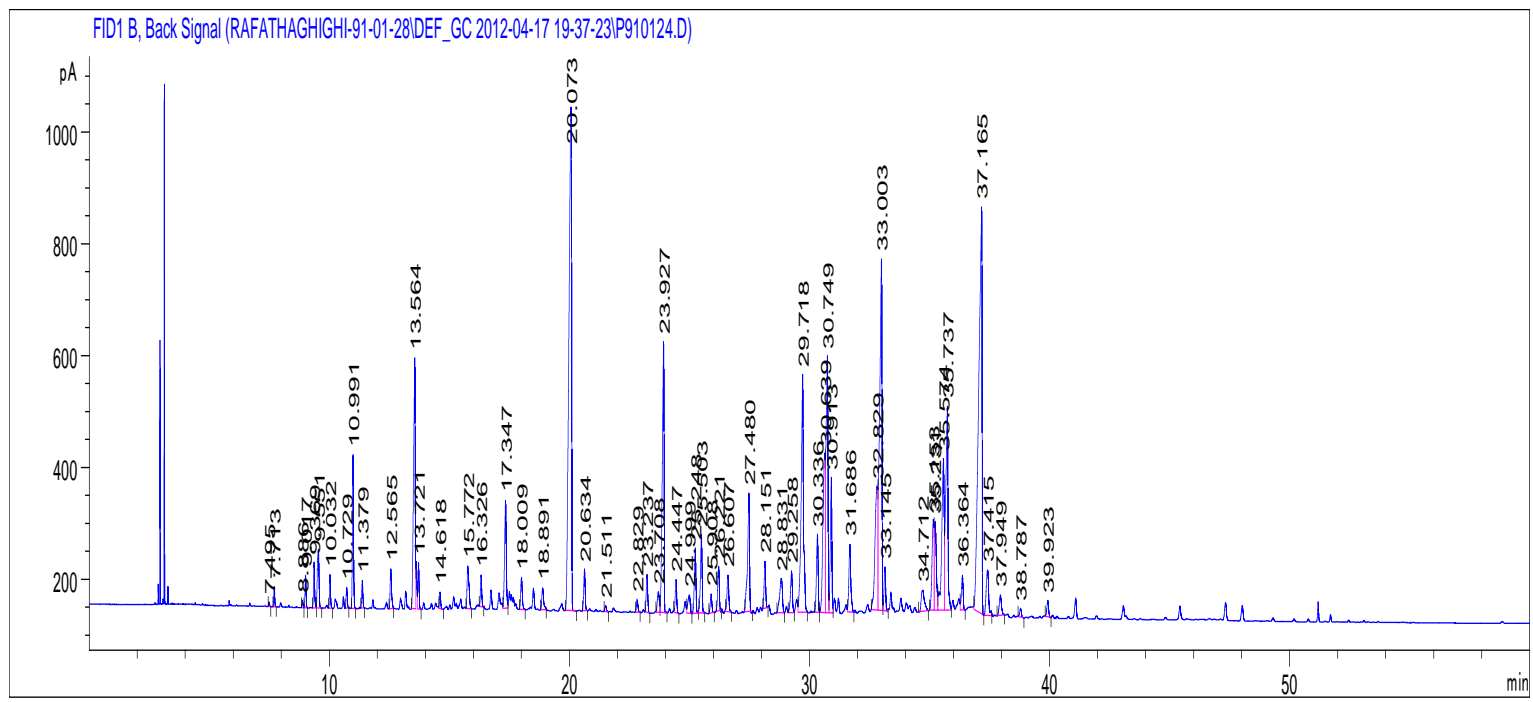

Figure3. GC-MS chromatogram of S. mirzayanii essential oil in $C$ region 


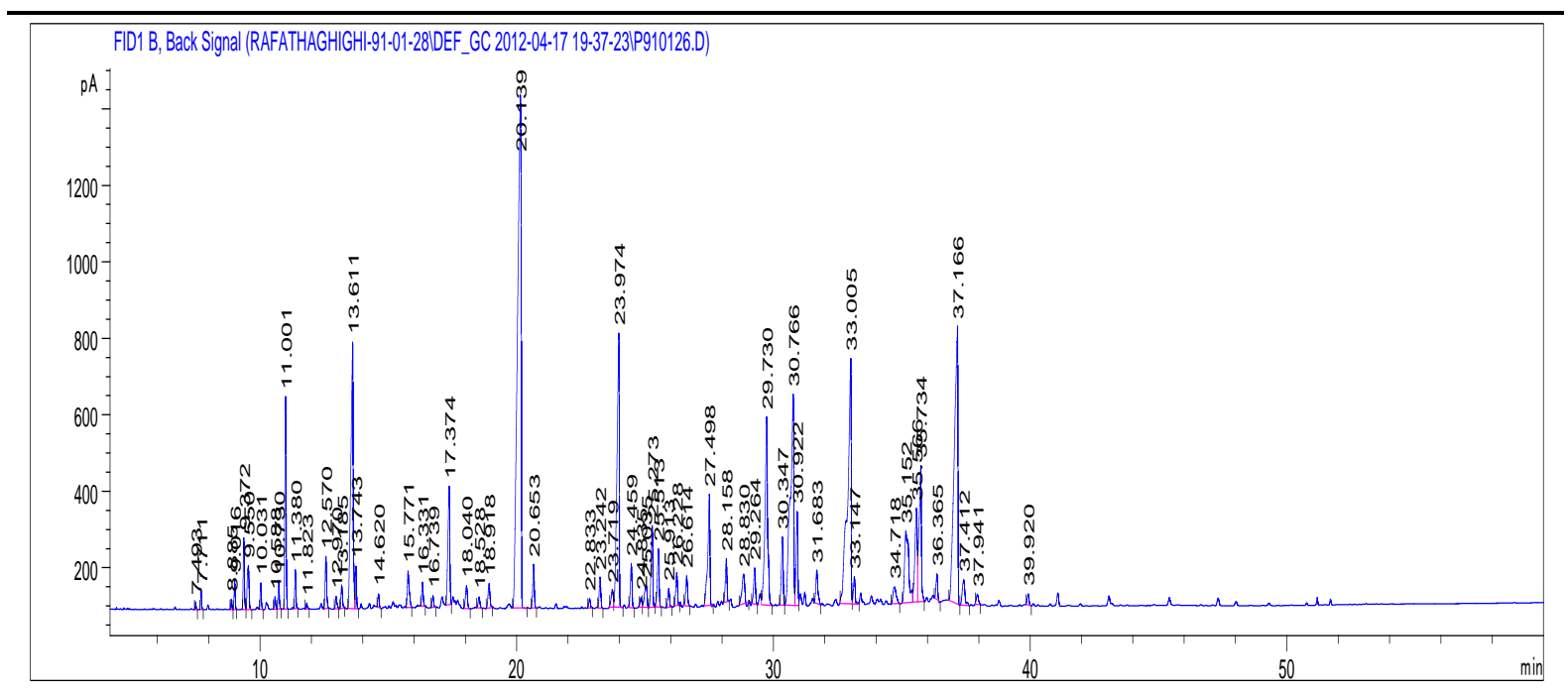

Figure4. GC-MS chromatogram of S. mirzayanii essential oil in D region

However, some major components as, linalool, linalyl acetate, 5- neo-cedranol, 7-epi- $\alpha$-selinene, $\alpha$ terpinyl acetate, 1,8-cineole,Spatolenol, $\alpha$-cadinol were common between all. These differences in the essential oil compositions in different regions can be credited to several environmental agents such as climatic conditions, seasonal and geographical or ontogenesis variations(17).There are many reports in the literature showing the variation in the chemical composition of the essential oil with respect to geographical regions $(18,19,20$, and 21).

According to the results, by increasing of moisture content, silt, clay and lime percentage increased essential oil of $S$. mirzayanii, but essential oils of this plant are reduced by increasing of electrical conductivity, phosphorous, nitrogen and sand percentage. Potassium levels had no effect on the amount of essential oil. Percentage of essential oil increased by increasing elevation, but Linalyl acetate (one of the major constituents of the essential oil) was reduced.

In this study the number of components (forty-six) in $S$. mirzayanii essential oil were higher than previous reports in this plant. In present study, linalyl acetate and 5- neo-cedranol were principle component in S. mirzayanii, while Mirza et al. (22) reported that, linalool, linalyl acetate, 1,8-cineol, terpinenyl acetate were the main constituents of the $S$. mirzayanii essential oil. Javidnia et al.(7) reported that spathulenol, $\delta$-cadinene, linalool, $\alpha$-terpinyl acetate, $\alpha$-cadinol, $\beta$-eudesmol, cubenol and linalyl acetate were the main components of $S$. mirzayanii essential oil. In another study by Yamini et al.(8) linalyl acetate, 1,8-cineole, linalool and 8-acetoxy linalool were reported to be the major components in S. mirzayanii essential oil.

\subsection{Antimicrobial Activity of Essential Oils}

The antimicrobial activity of $S$. mirzayanii essential oils were evaluated against standard strain of Staphylococcus aureus (ATCC 6538), Shigella dysenteriae (RI366), Escherichia coli (O157:H7 EPEC (M) by using disc diffusion method. Our results showed that, S. mirzayanii extract has significant antimicrobial properties against these microorganisms. The effectiveness of leaf essential oil is demonstrated by the size of the inhibition zone around the filter paper disk on microbial growth, which is typically expressed as the diameter of the inhibition zone in millimeter (23). This results showed different inhibition zone against Sh. dysenteriae (8, 9, 10, 12, 13.33,15.67 mm), E. coli (8.67, $8.67,10,11.33,12.33$ and $14.33 \mathrm{~mm})$ and $S$. aureus $(8,10.33,11.33,12.67,14$ and $17.67 \mathrm{~mm})$ with different concentrations of $S$. mirzayanii essential oil (0.625, 1.25, 2.5, 5, 10 and 20), respectively.

In this study, Escherichia coli was the most resistant microbe and Shigella dysenteriae was the most sensitive (Figure 5). In all treatments, inhibitory effect of the essential oil was increased by increasing concentration of essential oil. Minimum inhibitory concentrations (MICs) were determined and the MIC value was $0.625 \mu \mathrm{l} / \mathrm{mlin}$ all microorganisms. This activity is generally correlated to the chemical composition of the oil (11). These results suggest that antimicrobial activity in S. mirzayanii results from the phenolic compounds. The diameters of inhibition zones ranged from 8 to $17.67 \mathrm{~mm}$ including the diameter of paper disc $(6 \mathrm{~mm})$. The results are summarized in Table 9. 

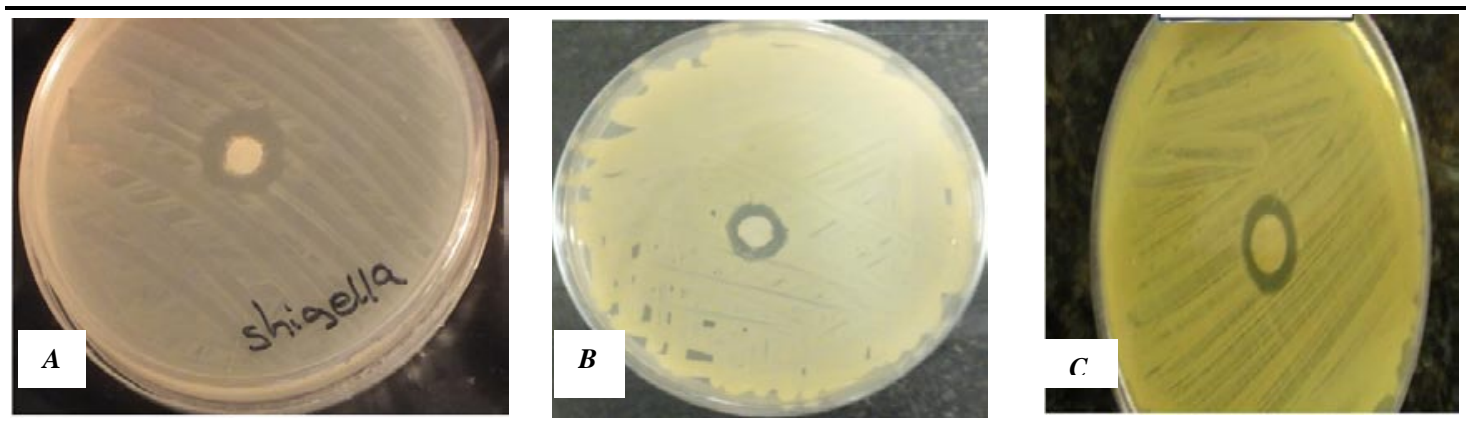

Figure5. Antibacterial activity of S. mirzayanii leaf essential oil against 3 selected bacteria (A: Sh. Dysenteriae, $B$ : S. aureus and C: E. coli) by disc diffusion.

Table9. Antibacterial activities of extracts of S. mirzayanii against bacterial test organism

\begin{tabular}{|c|c|c|c|c|c|c|}
\hline \multicolumn{7}{|c|}{ zone of inhibition (mm) } \\
\hline Microorganism & \multicolumn{6}{|c|}{ essential oil of $S$. mirzayanii $(\mathrm{ul} / \mathrm{ml})$} \\
\hline & 0.625 & 1.25 & 2.5 & 5 & 10 & 20 \\
\hline Shigella dysenteriae & $8 \mathrm{~b}$ & 9a & $10 \mathrm{a}$ & $12 \mathrm{a}$ & $13.33 a$ & $15.67 \mathrm{a}$ \\
\hline Escherichia coli & $8.67 \mathrm{~b}$ & $8.67 \mathrm{~b}$ & $10 a$ & $11.33 \mathrm{~b}$ & $12.33 \mathrm{~b}$ & 14.33b \\
\hline Staphylococcus aureus & $8 \mathrm{~b}$ & 10.33 & $11.33 \mathrm{~b}$ & $12.67 \mathrm{a}$ & $14 \mathrm{c}$ & $17.67 \mathrm{c}$ \\
\hline
\end{tabular}

Each value in the table was obtained by calculating the average of three experiments.

Diameter of inhibition zone including disc diameter of $6 \mathrm{~mm}$

Good antimicrobial activity of S. mirzayanii extract against experimental bacteria could be attributed to high amount of major components as 5-neo-cedranol, linalool, linalyl acetate, $\alpha$-terpinyl acetate, 1,8-cineol and other valuable components in oil. Several researches on the antimicrobial activity of the essential oils of many Salvia species have been carried out, demonstrating that among the components of the oil, some of them showed strong antimicrobial activity (24). These results suggest that $S$. mirzayanii extract has high antimicrobial activity. This is in line with the observation of other authors who found antimicrobial properties of the essential oils of this plant. The essential oil of Salvia tomentosa showed antibacterial activity against eight microorganisms (25).

Yousefzad et al. (26) reported S. chloroleuca oil exhibited moderate to high antimicrobial activity, especially for Bacillus subtilis, Staphylococcus epidermidis and $S$. aureus. Results of Bouaziz et al. (27) confirmed that $S$. officinaliscs had inhibitive effect on bacterial strains including Gram+ and Gram- of rods and cocci.

S. przewalskii oil also showed an antimicrobial activity against Staphylococcus aureus and $S$. epidermidis strains (26). Kabouche et al. (28) demonstrated that essential oil obtained from roots of Salvia jaminiana has antibacterial activity. The essential oils of S.santolinifolia, S. hydrangea and $S$. mirzayanii have the antimicrobial property. Furthermore, the antimicrobial property of $S$. myrzayanii oil was superior to others (9). Results of Bahadori et al. (29) showed that the volatile oil of $S$. santolinifolia could be considered as a rich source of natural agents for several uses as antibiotics against human pathogenic microbes.

The strong positive correlations found between inhibitory concentrations of $S$. mirzayanii essential oil and diameter of inhibition zone of Sh. dysenteriae $(\mathrm{r} 2=0.9051), E$. coli $(\mathrm{r} 2=0.8758)$ and $S$. aureus $(\mathrm{r} 2=0.9081)$ confirm the above remark (Figure 6).
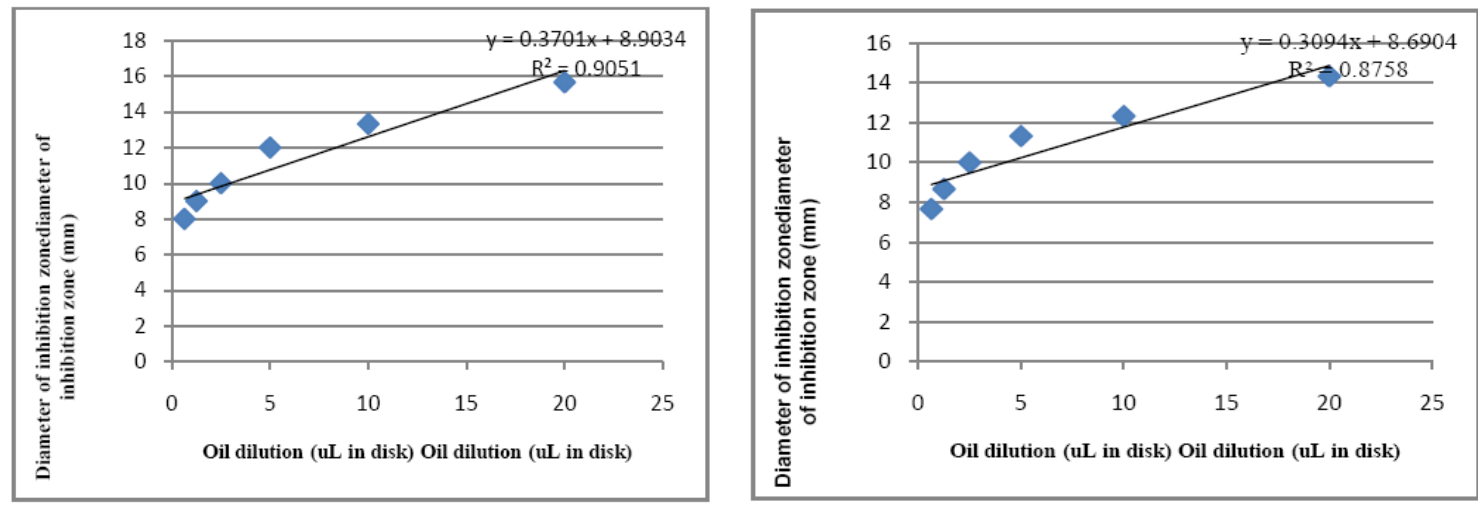


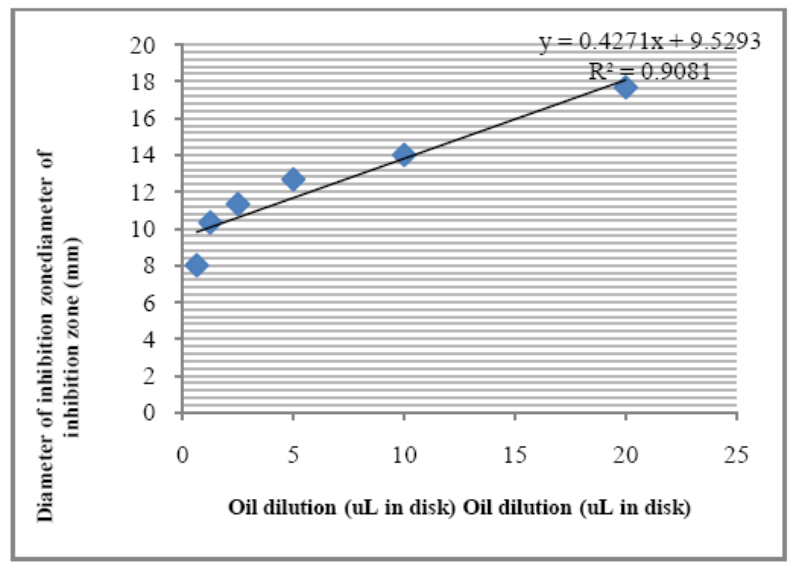

Figure6. Correlations between inhibitory concentrations of S. mirzayanii essential oil and diameter of inhibition zone of Sh. Dysenteriae (Top-left), S. aureus (Top-right) and E. coli (Bottom)

\section{Conclusion}

The findings of this study indicated that $S$. myrzayanii has an antimicrobial essential oil. These essential oils of $S$. myrzayanii can be possibly used as an antimicrobial agent in control of oral pathogens. This oil could be applied for formulation of new natural antibiotics. Differences observed in the chemical composition and oil yield, between different regions may be due to climatic conditions and soil properties. From these results it can be concluded that $S$. myrzayanii cultivation in areas with moist, silt, clay and lime soil and increasing elevation can be enhanced essential oil of $S$. myrzayanii.

\section{ACKNOWLEDGEMENTS}

The authors would like to acknowledge Islamic Azad University, Jahrom Branch (Iran), for financial support of this research.

\section{REFERENCES}

[1] K. H. Rechinger, Flora Iranica. Akademische Druck- und Verlagsanstalt, Graz, 152 (1982).

[2] SoltanipoorM. A., Phenology of Salvia mirzayanii Rech. f. \& Esfand in different elevations of Hormozgan province. Pajouhesh- va-Sazandegi, 65, 34-38(2005).

[3] M. Li, Q. Li, C. Zhang, N. Zhang, Z. Cui, L. Huang, andP.Xiao, An ethnopharmacological investigation of medicinal Salvia plants (Lamiaceae) in China. Acta Pharmaceutica Sinica B, 3(4), 273-280 (2013).

[4] ZarshenasM. M.and KrennL.,Phytochemical and pharmacological aspects of Salvia mirzayanii Rech. f. \& Esfand. Journal of evidence-based complementary \& alternative medicine, 20(1), 6572 (2015).

[5] BautistaE., Toscano R. A.and OrtegaA.,5, 10-seco-neo-Clerodanes and neo-Clerodanes from Salvia microphylla. Journal of natural products, 77(4), 1088-1092(2014).

[6] FuZ., WangH., HuX., Sun Z. and HanC., The pharmacological properties of salvia essential oils. Journal of Applied Pharmaceutical Science, 3(7), 122(2013).

[7] JavidniaK., MiriR., KamalinejadM. and NasiriA.,Composition of the essential oil of Salvia mirzayanii Rech. f. \& Esfand from Iran. Flavour and fragrance journal, 17(6), 465-467 (2002).

[8] YaminiY., KhajehM., GhasemiE., Mirza M.and JavidniaK., Comparison of essential oil compositions of Salvia mirzayanii obtained by supercritical carbon dioxide extraction and hydrodistillation methods. Food Chemistry, 108(1), 341-346(2008).

[9] Sonboli A., BabakhaniB. and MehrabianA. R.,Antimicrobial activity of six constituents of essential oil from Salvia. Zeitschrift für Naturforschung C, 61(3-4), 160-164 (2006).

[10] Zomorodian K., GhadiriP., Saharkhiz M. J., MoeinM. R., MehriarP., BahraniF. andFaniM. M., Antimicrobial activity of seven essential oils from Iranian aromatic plants against common causes of oral infections. Jundishapur journal of microbiology, 8(2)(2015). 
[11] HaghighatM. H., AlizadehA.and NouroznejadfardM. J.,Essential oil composition and antimicrobial activity in Iranian Salvia mirzayanii Rech. \& Esfand. Advances in Environmental Biology, 1985-1990 (2012).

[12] Fathi E.and SefidkonF., Influence of drying and extraction methods on yield and chemical composition of the essential oil of Eucalyptus sargentii. Journal of Agricultural Science and Technology, 14(5), 1035-1042(2012).

[13] Adams R.P., Identification of Essential Oil Components by Gas Chromatography/Mass Spectroscopy, fourth ed. AlluredPubl. Corp., Carol Stream, IL (2007).

[14] National Committee for Clinical Laboratory Standards,Performance standards for antimicrobial disk susceptibility tests. Approved standard M2- A6. National Committee for Clinical Laboratory Standards, Wayne, $\mathrm{Pa}(1997)$.

[15] TepeB., SokmenM., SokmenA., afereraD.D. and PolissiouM., Antimicrobial and antioxidative activity of the essential oil and various extracts of Cyclotrichium origanifolium (Labill.) Manden. \& Scheng. Journal of Food Engineering, 69(3), 335-342 (2005).

[16] MurrayP. R., BaronE. J., Jorgensen J. H., Landry M. L.and PfallerM. A., Manual of clinical microbiology. Manual of clinical microbiology.1, (Ed. 9), 1-1267(2006).

[17] Alizade A. andShaabaniM., Essential oil composition, phenolic content, antioxidant and antimicrobial activity in (salvia officinalis L.) cultivated in Iran. Advances Environment Biol, 6, 221-226 (2012).

[18] Uribe-Hernández C. J., Hurtado-RamosJ. B., Olmedo-ArcegaE. R. and Martinez-SosaM. A., The essential oil of Lippia graveolens HBK from Jalisco, Mexico. Journal of Essential Oil Research, 4(6), 647-649(1992).

[19] CeliktasO. Y., KocabasE. H., edirE.B., SukanF. V., Ozek T. and Baser K. H. C., Antimicrobial activities of methanol extracts and essential oils of Rosmarinus officinalis, depending on location and seasonal variations. Food Chemistry, 100(2), 553-559 (2007).

[20] Van VuurenS. F., ViljoenA. M., Özek T., DemirciB. and BaşerK. H. C., Seasonal and geographical variation of Heteropyxis natalensis essential oil and the effect thereof on the antimicrobial activity. South African Journal of Botany, 73(3), 441-448(2007).

[21] ViljoenA. M., S.S. F.Petkar, Vuuren V., FigueiredoA. C., Pedro L. G.and BarrosoJ. G., The Chemo-Geographical Variation in Essential Oil Composition and the Antimicrobial Properties of" Wild Mint"--Mentha longifolia subsp. polyadena (Lamiaceae) in Southern Africa. Journal of Essential Oil Research, 18, 60-65(2006).

[22] MirzaM., Bahernik Z.and JamzadZ., The Extraction and identification of the essential oil constituents of Salvia mirzayanii Rech. F. \& Esfand. Iranian Journal of Medicinal and Aromatic Plants Research, 19 (2),20-25 (2003).

[23] Priya B., GuptaV. K., Pathania D. and SinghaA. S., Synthesis, characterization and antibacterial activity of biodegradable starch/PVA composite films reinforced with cellulosic fibre.Carbohydrate polymers,109, 171-179 (2014).

[24] JavidniaK., MiriR., SoltaniM., Gholami M.andKhosraviA. R., Antimicrobial activity and chemical composition of the essential oils of six Iranian Salvia species. Chemistry of natural compounds, 44(5), 654-658 (2008).

[25] AznedarogluM. Z.H., Karabay N. U. and ZeybekU., Antibacterial activity of Salvia tomentosa essential oil. Fitoterapia, 72(7), 829-831 (2001).

[26] YousefzadiM., SonboliA., Ebrahimi S. N.and HashemiS. H., Antimicrobial activity of essential oil and major constituents of Salvia chloroleuca. Zeitschrift für Naturforschung C, 63(5-6), 337340 (2008).

[27] BouazizM., YanguiT., SayadiS. and DhouibA., Disinfectant properties of essential oils from Salvia officinalis L. cultivated in Tunisia. Food and Chemical Toxicology, 47(11), 27552760(2009).

[28] Kabouche A., BoutaghaneN., KaboucheZ., SeguinE., Tillequin F.and BenlabedK., Components and antibacterial activity of the roots of Salvia jaminiana. Fitoterapia, 76(5), 450-452(2005).

[29] BahadoriM. B., Valizadeh H. and FarimaniM. M., Chemical Composition and Antimicrobial Activity of the Volatile Oil of Salvia santolinifolia Boiss. From Southeast of Iran.Pharm science, 22, 42-48(2015). 